\title{
Law Review Of Dispute Resolution In The Land Acquisition For Development For Public Interest In Tegal Regency
}

\author{
Vita Purnamiati ${ }^{1}$, Sufi Hamdani Kurniawan ${ }^{2}$ and Gunarto ${ }^{3}$
}

Abstract. The purpose of this study was to determine: 1) Implementation of land acquisition for the construction of highways in the public interest, Tegal Regency. 2) Settlement of disputes in the implementation of land acquisition for the construction of public interest. 3) Obstacles and solutions in the procurement of land for public purposes in Tegal regency.

The approach method in this research is juridical empirical research that emphasizes the behavior of individuals or communities in connection with the law. The data used are primary and secondary data obtained through interviews and literature, whereas the method of analysis with descriptive analysis method and qualitative analysis.

Results of the research results can be concluded: 1) Implementation of land acquisition for public purposes, starting from planning, location determination, the establishment of the land procurement committee, price assessment, deliberation, decision and compensation stage damnification; 2) Settlement of disputes of land acquisition in the public interest the construction of toll roads in Tegal regency can be done with the courts and lanes deliberation. Tegal society more choose the path of deliberation for reasons more cost effective. Settlement of disputes by consultation carried out continuously and intensely to achieve a fair deal. 3) Obstacles and solutions in the procurement of land for public purposes in Tegal their third-party intervention, the buying and selling of land free, the process of inheritance that has not been behind the name, the pricing of compensation is not appropriate and the knowledge society that is lacking in the field land and construction of public interest. The solution to this committee is to socialize and intense deliberations to happens a fair deal for both sides.

Keywords: Land Dispute; Land Acquisition; Public Interest.

\section{Introduction}

Land has a meaning and an important role for human life. Land is the asset of Indonesia which is the basis of development towards a just and prosperous society. Therefore, its use should be based on principles that grew and developed in Indonesian society. In this regard should be avoided their efforts to make the land as a commodity, the object of speculation and other things that are contrary to the principles contained in Article 33 paragraph (3) of the Act of $1945 .{ }^{4}$

through the right dominate State here the State as the ruling body will be able to continue to control or direct the management function of the earth, water and air space and the natural riches contained therein in accordance with existing regulations and policies, namely within the scope of judicial control of the public aspect. ${ }^{5}$ However, for the construction of public facilities such as the above, require land as a container.

1 Students Master of Notary, Sultan Agung Islamic University in Semarang email panda.milkncoffee.phoneshop@gmail.com

2 Students of Master of Law, Faculty Of Law, Universitas Islam Sultan Agung email Sufikurniawan12@gmail.com

${ }^{3}$ Faculty of Law, UNISSULA

${ }^{4}$ Arie Sukanti, 2008, Kewenangan Pemerintah dibidang Pertanahan, Rajawali, Jakarta, p.83

${ }^{5}$ Muhammad Bakri, 2007, Hak Menguasai Tanah Oleh Negara (Paradigma Baru Untuk Reformasi Agraria), Citra Media, Yogyakarta,, p. 5 
In terms of land supply is still widespread, the construction of public facilities do not encounter any problems. But the problem of land constitute natural resources are limited, and never grow in extent. Land provided many clung to the rights (land rights), and the country has been very limited land supply.

Problem procurement the soil is very vulnerable in handling, because it concerns the lives of many people, when seen from the government's need for land for development purposes, it is understandable that the state land available is limited, therefore oneonly how that can be achieved is by freeing the land owned by the community, whether that has been mastered with rights under customary law and rights Other according to the BAL. ${ }^{6}$

In practice, known as 2 (two) types of land acquisition, first by land acquisition government in the public interest and the second land acquisition for private interests include the interests of commercial and non-commercial interests or not social. ${ }^{7}$ Procurement of land in question here is the activity of providing soil by proper compensation, and fair to the parties entitled to, such as the party that controls the land or has the land procurement object. $^{8}$ Meanwhile, replace decrease the replacement viable and fair to the parties entitled to the land acquisition process. As for the aspects of proper compensation should in principle meet the three aspects, namely economic, sociological aspects, and philosophical aspects. ${ }^{9}$

Road as a means of transportation is absolutely necessary to support its increasingly complex development, is no exception with the Tegal Regency is a regency in Central Java Province who passed by the Trans Java Toll Road Project. The project, leaving the problem of land acquisition. The implementation of the project related to legislation that Presidential Decree No. 55 Of 1993 and Presidential Decree No. 36 Of 2005 on Land Procurement for Development for Public Interest was amended by Presidential Decree No. 2 of 2012 concerning amendments to the Presidential Regulation No. 36 2005 on Land Procurement for Development in the Public Interest.

Construction of Toll Road Project in Tegal require long land and it will automatically involve many parties and emerging issues related to land acquisition. The parties in question here are those who have land rights to be passed by the building and those who need land, in this case the Government. Construction of roads in Tegal is dedicated to the development of the whole society. In addition to the national road construction is also expected to be a growth driver in the region economy in Tegal. Construction of roads in Tegal regency implemented by the Central Government and its Central Java Provincial Government and the Regional Government of Tegal. Implementing the Central Government as physical development while Tegal regency administration is, as the executor of land acquisition / land provider.

Based on this background, lifted the title: "Law Review Of Dispute Resolution In The Land Acquisition For Development For Public Interest In Tegal Regency", This study sought to answer the problem ofimplementation of land acquisition for the construction of toll roads in the public interest in Tegal, settlement of disputes in the implementation of land acquisition for the construction of toll roads in the public

\footnotetext{
${ }^{6}$ Adrian Sutedi, 2008, Implementasi Prinsip Kepentingan Umum Dalam Pengadaan Tanah Untuk Pembangunan, Ed. 1, Cet. 2, Sinar Grafika, Jakarta, p. 45

7Bernhard Limbong, 2011, Pengadaan Tanah Untuk Pembangunan:Regulasi, Kompensasi Penegakan Hukum, Pustaka Margareta, Jakarta p. 129.

${ }^{8}$ Article 1 (2) of Act No. 2 of 2012 on Land Procurement for Development in the public interest. ${ }^{9}$ Bernhad Limbong, 2011, Pengadaan Tanah untuk Pembangunan, Margaretha Pustaka, Jakarta, p. 369.
} 
Volume 6 Issue 2, June 2019

interest in Tegal, and barriers and solutions in the implementation of land acquisition for the construction of highways in the public interest, Tegal Regency.

The method used in this research is juridical empirical. Juridical empirical research that focuses on the behavior of individuals or communities in connection with the law. ${ }^{10}$ Specification of the research is descriptive. Primary data were collected by interview. Type of interview used in this study using a free guided interview, is a combination of free and guided interview. ${ }^{11}$ Secondary data is data obtained from a review of the literature or the review of the literature or library materials related to the problem or research materials that are often referred to legal materials. ${ }^{12}$ Analysis of the data used in this study is a qualitative analysis.

\section{Results and Discussion}

\subsection{Implementation of Land Procurement for Public Interest Toll Road Development Based on Local Regulation in Tegal}

There are seven regencys in Tegal affected by the construction of the Trans Java toll road segment Pejagan-Pemalang. In this construction of the central government through the local government made the procurement of land, assisted by the Land Agency of Tegal. The regencys which are sub-regency development project Dukuhturi, Adiwerna, Gutters, Tarub, Pengkah, Suradadi Warureja ${ }^{13}$

Stages in the implementation of land acquisition for public purposes set forth in Article 13, namely: planning, preparation, execution; delivery of outputs. Act No. 2 In 2012, in conjunction with Presidential Regulation No. 71 of 2012 stipulates that the land acquisition for public interest organized by the National Land Agency. The procurement of land for public purposes is done by the Head Office of the Provincial National Land Agency. Taking into account the efficiency, effectiveness, geographical conditions, and human resources, Head of the Regional Office of the Provincial National Land Agency can entrust the Head of the Regency Land Office / City as Chief Executive of the Land Acquisition (PPT). In summary execution procedure of land acquisition in Tegal regency is as follows: ${ }^{14}$

10 Soerjono Soekanto and Sri Mamadji, 2009, Penelitian Hukum Normatif: Suatu Tinjauan Singkat, RajaGrafindo Persada, Jakarta, p.1

${ }^{11}$ Ibid, p. 84

${ }^{12}$ Mukti Fajar and Yulianto, 2010, Dualisme Penelitian Hukum Normatif and Empiris, Pustaka Pelajar, Yogyakarta, p. 156

${ }^{13}$ Interview with Bp. Septiadi, Land Acquisition Implementation Committee for Ruas PejaganPemalang, February 1st, 2019

${ }^{14}$ Interview with Bp. Saifulah, Head of Sub. Section Land Regulation Government in Tegal District Land Office, dated February 1, 2019 


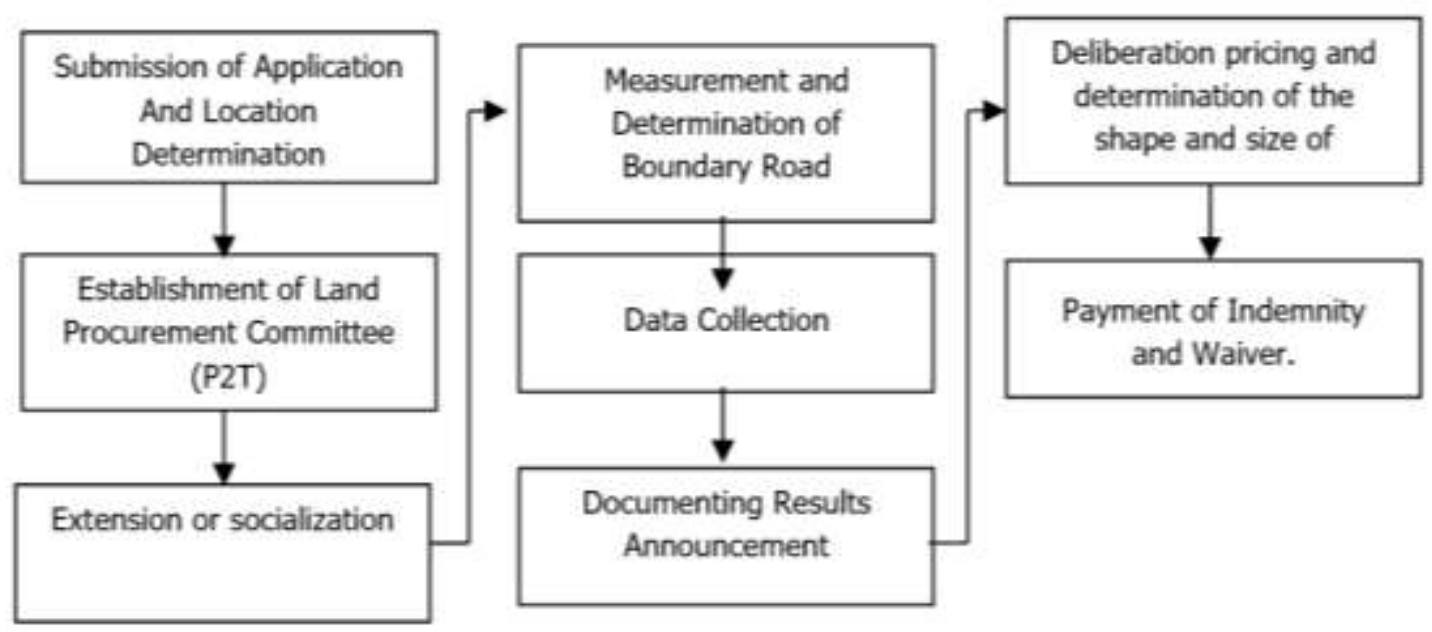

Submission of application are set forth in the form of a proposal, application of proposals for the construction of Trans Java Toll Road Segment Pejagan - Pemalang carried out by the agency, namely the Directorate General of Highways Ministry of Public Works to the Land Office of Central Java province, after the petition is filed then held a coordination with the Provincial Government of Central Java it is the Central Java Governor, then Governor ordered the head of the land office of Central Java province to coordinate with relevant parties, in this case the regional Government of each of the areas affected by the construction of the motorway both regents / mayors of each region, the land office each of the areas affected by the construction of the motorway, and agencies every area related to the construction of the toll road.

Coordination is done to conduct research petitioned the suitability of land for development, whether as intended or not, of course taking into account the Spatial Plan (RTRW) both Spatial Plan (RTRW) national, provincial, and regency / city. After the procedure / coordination is carried out and are in accorand ce with the Spatial Plan of the Regency / Municipal affected by the construction of the Trans Java toll road that the governor will issue a Decree (SK) permits the determination of the location.

Construction of the facility to the public interest which requires the land by means of land acquisition did have to request it before being held to determine the location of land, in this case the construction of Trans Java Toll Road The appeal was filed by the Directorate General of Highways Ministry of Public Works, by filing an application letter extension location determination Land Office to Central Java province whose contents regarding extension request approval letter designation of development (SP2LP) of trans-Java toll roads in the province of Central Java. Once the petition is received by the Central Java provincial land office then conducted coordination with the land offices in each of the areas affected by the construction of the toll road.

Land procurement committee has the lead role in the liberation and the implementation of land acquisition. Land Procurement Committee (P2T) is an arm of the government as an apparatus that occupy the forefront, in any kind of land acquisition land for public purposes or other purposes. Land Procurement Team (TPT) and the Land Procurement Committee (P2T) Tegal implement socialization / counseling to explain the benefits, goals and objectives to the community development and in order to obtain the willingness of the owners. Socialization / counseling held in place specified in the letter of invitation made by the Land Acquisition Committee. In Tegal regency itself socialization conducted in each village hall for the village whose territory is affected by the toll road construction project itself. In Tegal regency itself 
socialization of land acquisition for the construction of toll roads has been implemented in all areas affected by the land acquisition that includes 32 villages spread over 7 regencys, including subregency of Dukuhturi, Adiwerna, Gutters, Tarub, Pengkah, Suradadi, and sub Warureja. ${ }^{15}$

Dissemination / counseling land acquisition carried out by the land procurement committee performed a total of approximately 7 times, counseling is done by the Land Acquisition Committee with the people whose land catch the project of Toll Road development be conducted face to face in the local village hall. ${ }^{16}$ Having conducted socialization and counseling about their development plans Toll Road of PejaganPemalang, Tegal regency TPT and P2T start land acquisition activities by measuring and installation of markers. The stakes installation carried out by Land Procurement Team (TPT) with a basic installation of markers that then take measurements and determination of the boundaries of land parcels affected by the toll road construction plan Tegal Regency Land Office.

After measurement and determination of the boundaries of the road at the location of the affected highway construction projects, and then carried out the data collection. The data collection was conducted to determine clearly and in detail related to the physical and nonphysical conditions of the land affected by the toll road construction project. ${ }^{17}$ After logging on physical and non-physical condition of the land then made the announcement of the data collection has been done. Announcement of the results posted at the village office and local as well as the Regency Land Office for 30 days. Documenting Results of attachment is done in order to give the opportunity to citizens to challenge the results of the data collection. In addition to the announcement of results of data collection conducted attachment at the regency office and the office of the village carried the announcement also made through the website for 7 days and also through the mass media. ${ }^{18}$

In the acquisition, the stages of deliberation and determination of the form of damages is very influential in order to achieve the implementation of land acquisition. But a lot happened disagreements concerning the amount of compensation and restitution given those who need land with landowners, which can lead to disputes in land acquisition. Deliberation is the best way in determining the amount of compensation and if a way can be achieved consensus agreement between land owners and agencies that need the land can be said to be the highest decision, the best and cannot be contested by other parties.

After deliberation phase is completed and reached agreement, the next step is plelepasan rights. The release of land rights is an activity termination of the legal relationship between the holders of land rights to land held under their control with or without compensation proper and fair to the interests of others, resulting in land rights be abolished and the land rights back into state land or land directly controlled by the state. ${ }^{19}$

\footnotetext{
${ }^{15}$ Interview with Hima, Land Procurement Committee in the construction of the Trans-Java Toll Road in Tegal, February 1st, 2019

16 Interview with less Halimah, residents affected by the toll road construction project dikecamatan Adiwerna, February 1st, 2019

${ }^{17}$ Interview with Saifulah, Head of Sub. Section Land Regulation Government in Tegal District Land Office, dated February 1, 2019

${ }^{18}$ Interview with the Head District of Adiwerna, February 1st, 2019

19 Urip Santoso, "Perlindungan Hukum Dalam Pengadaan Tanah Untuk Kepentingan Umum", Jurnal Magister Hukum, Volume 5 Nomor 1, Program Pascasarjana Program Studi Magister Hukum, Universitas Wisnuwardhana, Malang, April 2014, p. 21.
} 


\subsection{Settlement in the Land Procurement for Public Interest Development Highway in Tegal Regency}

Construction of Trans-Java Toll Pejagan - Pemalang become one of the priorities of development, as contained in the Central Java Provincial Regulation, No. 6 of 2010, details of spatial plans in Central Java province in 2009 - 2029. Construction of toll road is intended to realize the Provincial Infrastructure Network System to support the development of strategic importance in Central Java.

Dispute resolution can be done through two (2) ways by the parties to the dispute, namely:

- Settlement of disputes in court. Settlement of disputes in court, which is one of the parties to the dispute filed a lawsuit to the Administrative Court if the nature of the dispute is a dispute over the state administration, or filed a lawsuit in the Regency Court if the nature of the dispute is a civil dispute. Settlement of disputes through a court case known as litigation.

- Settlement of disputes out of court. Dispute resolution outside the court, the parties to a dispute agree to settle disputes by way of deliberation to reach an agreement (consensus). Settlement of disputes out of court in the form of negotiation, conciliation, mediation, and arbitration. Negotiation, conciliation, mediation and arbitration or alternative dispute resolution Alternative Dispute Resolusition, that the disputing parties can settle disputes out of court with or without the help of a third party.

Providing dispute settlement land for public purposes motorway in Tegal regency, the majority party is using deliberations. In the meeting between Land Agency (BPN RI) and parties entitled may occur not reach an agreement on the shape and / or besarya damages. By not achieve this agreement, the dispute could arise between Land Agency (BPN RI) and beneficiaries.

Implementation of the deliberations conducted to determine the amount of compensation to be be given by Land Procurement Team to residents affected by land acquisition for the construction of toll roads in accorand ce with the principles of deliberation, In the implementation of the process of negotiation / deliberation compensation isa lot of obstacles, so that the process of consultation and ongoing approach by Land Procurement Committee to the citizens of the land affected by the construction of toll roads. This consultation process is done repeatedly and matters discussed in the meeting include:

- Development plan for public use at the site.

- The shape and / or the amount of compensation.

Deliberation forms / and or the amount of compensation based on the SVTO (taxable value), the agreement between the parties, and the assessment results

In the execution of land procurement, dispute settlement is done with deliberation track. However, there is no doubt in the process of implementation of the consensus there are many problems that occur. When the deliberation process there are many obstacles encountered, but the obstacles are most prevalent is the problem of the price agreement between the assessment team ground with people who own the land, the incompatibility of prices on offer at the asking price, so there is the discovery of a bright spot on arrangement. However, the approaches made by the land procurement committee with communities affected by the construction of the highway leading to the deal price. ${ }^{20}$

${ }^{20}$ Interview with the Head Dukuhturi Tegal district, February 1, 2019 
From the result of deliberation and determining the amount of compensation for the people who agree with the price determined by the committee, will be created passbook by land procurement committee. Where the passbook is then the compensation money will be directly transferred by land procurement committee to the people whose land affected by the construction of the highway through the account. This is done to reduce the fraud irresponsible elements that will be detrimental to the community.

Damages done by the land procurement committee by way of a new savings account opened for the recipients of compensation. This is done so that people are not harmed by the pieces performed by the person / persons responsible, which will not it hurt the community. In addition, regarding the land acquisition committee's performance has been good, it can be seen from the amount of land that successfully freed.

\subsection{Obstacles and Solutions in the Implementation of Land Procurement for Public Interest Development Highway in Tegal Regency}

Problems of land acquisition is very vulnerable in handling, because in it concerns the livelihood of many people, when seen from the government's need for land for development purposes, it is understandable that the state land available is limited, therefore the only way that can be taken is to liberate the land belongs to the people, whether they have mastered with rights under the Customary Law as well as other rights according to the BAL. ${ }^{21}$ In any implementation of land acquisition for development interests general, There are always obstacles. In the construction of the Trans-Java Toll Road Pejagan- Pemalang in Tegal regency, there are several obstacles faced, namely:

- The intervention of a third party which is one factor unflow implementation of land acquisition.

- The sale and purchase of land (land for sale) performed by the owner of the land freely, without reporting to the authorities on land issues, in this case the BPN.

- The process of heirs inherit the land which is wrong, but the only process-heir inheritance in this land is not directly behind the name by the heirs.

- Less public knowledge in terms of land.

Application of the principle of fairness in land procurement regulations, the development of affected communities should receive compensation that can restore their socio-economic conditions at least equal to the state prior to release or revocation of land rights. In essence, fairness is an attitude to treat people in accorand ce with their rights. And that the rights of every person are recognized and treated in accorand ce with the dignity and dignity, Which are equal, the same right and obligations, without distinction of race, ancestry, religion, and class. The principle of the conception of justice is to show rights and fundamental freedoms and to determine the proper mapping, this affects the efficiency problems, coordination and stability. Justice has a particular priority becomes the main virtue of the institution. ${ }^{22}$

To achieve justice one way that can be achieved is by consultation or negotiation. Deliberation is made to reach an agreement betweensecondparties in the

${ }^{21}$ Muhammad Elmo Shidiq, Peran Notaris Dalam Transaksi Pengadaan Tanah Untuk Lokasi Pembangunan Komplek Perkantoran Pemerintah Kabupaten Sekadau, Jurnal Akta Unissula Semarang Vol 5 No 1 March 2018

22 John Rawls, 2006, Teori Keadilan Dasar-Dasar Filsafat Politik Untuk Mewujudkan Kesejahteraan Sosial Dalam Negara "A Theory of Justice", Terj. Uzair Fauzan and Heru Prasetyo, Cetakan pertama, Pustaka Pelajar, Yogyakarta, p. 3 
implementation of land acquisition for public use. An essential element in the deliberations is the unity of opinion between the two sides on the issue. The will of each citizen is an integral part of the unity of this opinion. The result of their deliberations was a mutual agreement between all of the land owners and those who need land. Deliberation is made to reach an agreement on the compensation price andmechanismpayment and release of land rights. Similarly, the theory of legal certainty, the implementation of land acquisition must satisfy the principle of legal certainty, which is done in a way that has been set in the legislation in force, in which all parties know exactly the rights and obligations of each. Legal certainty should also be directed towards the provision of compensation to the land owners. However the society not only need regulations to ensure legal certainty in their relations with one another, but it is also justice. A good law should meet the elements of fairness and certainty simultaneously. In addition, the law also required serve the interests of society in order to provide the benefit.

\section{Closing}

\subsection{Conclution}

Based on the description and discussion above, the conclusion of researchers are as follows:

- Implementation of land acquisition for the construction of public interest in Tegal regency highway begins, the planning phase, determining the location, the establishment of the land procurement committee, price assessment stage, the stage of consultations if it has not reached an agreement, the decision point and compensation

- Settlement of disputes in the implementation of land acquisition for the construction of highways in the public interest Tegal majority held by consensus. Implementation of the deliberations conducted to determine the amount of compensation to be granted by the Land Procurement Team to residents affected by land acquisition for the construction of toll roads in accorand ce with the principles of deliberation. In the implementation of the process of negotiation / deliberation compensation is indeed a lot of obstacles, so that the process of consultation and ongoing approach by Land Procurement Committee to the citizens of the land affected by the construction of toll roads. This consultation process carried out some until an agreement is reached.

- Obstacles and solutions in the implementation of land acquisition for the construction of public interest motorway in Tegal are obstacles and solutions in the procurement of land for public purposes in Tegal their third-party intervention, the buying and selling of land free, the process of inheritance that has not been behind the name, the pricing of compensation is not appropriate and the knowledge society that is lacking in the area of land and construction of public interest. The solution to this committee is to socialize and intense deliberations to happens a fair deal for both sides.

\subsection{Suggestion}

Based on conclusion of the study the authors to put forward suggestions as follows:

- It is recommended that Local Government provides a deep understanding of land acquisition through the development of legal education, especially land law (Agricultural) to both the sub-regency government officials, rural / urban, as well as 
Volume 6 Issue 2, June 2019

community leaders and intensified so that the implementation is better in the future.

- Should people whose land affected by the construction of the Trans-Java Toll Road in Tegal better understanding of the social function of land, so do not ask for compensation is so high that the procurement of land for the construction of the Trans Java toll road can be completed.

\section{Bibliography}

\section{Books}

[1] Adrian Sutedi, 2008, Implementasi Prinsip Kepentingan Umum Dalam Pengadaan Tanah Untuk Pembangunan, Ed. 1, Cet. 2, Sinar Grafika, Jakarta

[2] Arie Sukanti, 2008, Kewenangan Pemerintah dibidang Pertanahan, Rajawali, Jakarta

[3] Bernhad Limbong, 2011, Pengadaan Tanah untuk Pembangunan, Margaretha Pustaka, Jakarta

[4] D.Y Witanto, 2012, Hukum Acara Mediasi Dalam Perkara Perdata Dilingkungan Peradilan Umum And Peradilan Agama Menurut PERMA No. 1 tahun 2008, Alfbeta, Bandung

[5] Dokumen Perencanaan Pengadaan tanah Tol Pejagan-Pemalang tahun 2015

[6] I Dewa Gede Atmadja, 2013, Filsafat Hukum Dimensi Tematis and Historis, Setara Press, Jawa Timur

[7] John Rawls, 2006, Teori Keadilan Dasar-Dasar Filsafat Politik Untuk Mewujudkan Kesejahteraan Sosial Dalam Negara "A Theory of Justice", Terj. Uzair Fauzan and Heru Prasetyo, Cetakan pertama, Pustaka Pelajar, Yogyakarta

[8] John Rawls, 2006, Teori Keadilan Dasar-Dasar Filsafat Politik Untuk Mewujudkan Kesejahteraan Sosial Dalam Negara "A Theory of Justice", Terj. Uzair Fauzan and Heru Prasetyo, Cetakan pertama, Pustaka Pelajar, Yogyakarta

[9] Maidin Gultom, 2008, Perlindungan Hukum Anak dalam Sistem Peradilan Piand a Anak di Indonesia, cet. Ke-1, Refrika Aditama, Bandung

[10] Muhammad Bakri, 2007, Hak Menguasai Tanah Oleh Negara (Paradigma Baru Untuk Reformasi Agraria), Citra Media, Yogyakarta

[11] Muhammad Elmo Shidiq, Peran Notaris Dalam Transaksi Pengadaan Tanah Untuk Lokasi Pembangunan Komplek Perkantoran Pemerintah Kabupaten Sekadau, Jurnal Akta Unissula Semarang Vol 5 No 1 March 2018

[12] Mukti Fajar and Yulianto, 2010, Dualisme Penelitian Hukum Normatif and Empiris, Pustaka1 Urip Santoso, Jurnal Magister Hukum, Volume 5 Nomor 1,Universitas Wisnuwardhana, Malang, April 2014

[13] Soerjono Soekanto and Sri Mamadji, 2009, Penelitian Hukum Normatif: Suatu Tinjauan Singkat, RajaGrafindo Persada, Jakarta

[14] Winahyu Erwiningsih and Fakhrisya Zalili Sailan,2018, Mengurai Benang Kusut Hak Ulayat, Inteligensia Media, Malang

\section{Legislation}

[1] Law of the Republic of Indonesia 1945

[2] Act No. 5 of 1960 on Basic Regulation of Agrarian

[3] Government Regulation Republic of Indonesia Number 24 of 1997 on Land Registration

[4] Act No. 2 of 2012 on Land Procurement for Development in the public interest 
[5] Agricultural Ministerial Regulation No. Chewing ATR Number 21 in 2017 concerning Confirmation Status Taxpayers On Land Services in the Ministry of Agricultural Environment and Spatial Planning / National Land Agency. 